\title{
Involvement of cell wall glucans in the genesis and persistence of the inflammatory reaction caused by the fungus Paracoccidioides brasiliensis
}

\author{
Celio L. Silva, ${ }^{1}$ Lucia M. C. Alves ${ }^{1}$ and Florêncio Figueiredo ${ }^{2}$
}

Author for correspondence: Celio L. Silva. Tel: +55 16 6333035. Fax: + 55166331586.

1,2 Department of Parasitology, Microbiology and Immunology', and Department of Pathology2, School of Medicine of Ribeirão Preto, University of São Paulo, 14049 - Ribeirão Preto, SP, Brazil

\begin{abstract}
The role of cell wall polysaccharides in leucocyte recruitment and granuloma formation in paracoccidioidomycosis was investigated. The inflammatory cells recruitment to the peritoneal cavity in rats inoculated with cell wall fraction (CW-265 or F1-265) from an avirulent strain of Paracoccidioides brasiliensis (Pb265), was greater than that observed for the cell wall fraction (CW-HC or F1$\mathrm{HC})$ recovered from the virulent strain (PbHC). Moreover, the inoculation of F1HC and F1-265 into the subcutaneous layer of mice resulted in the formation of nodular and not progressive granulomatous lesions. The size and mean time of evolution of these lesions was proportional to the degree of virulence of the sample from which they were derived. Analyses showed that both F1 fractions contained $\beta$-glucan and chitin. Only $\beta$-glucan was able to trigger attraction and concentric organization of polymorphonuclear neutrophils and macrophages at the inflammatory foci, and the difference in the concentration of this compound in the cell walls of PbHC and Pb265 could explain the inflammatory capacity exhibited by the two strains of $P$. brasiliensis.
\end{abstract}

Keywords: Paracoccidioides brasiliensis, leucocyte recruitment, $\beta$-glucan, inflammation, granuloma

\section{INTRODUCTION}

Paracoccidioidomycosis is a chronic progressive fungal infection characterized by granulomatous and suppurative inflammatory reactions (Restrepo et al., 1983). The disease is caused by Paracoccidioides brasiliensis and has been characterized as the most important systemic mycosis in Latin America. It seems to affect only humans and is the cause of high mortality in populations at risk in endemic countries. The initial pulmonary lesion is asymptomatic in most cases, and may then regress spontaneously, become latent, or disseminate contiguously and/or via the lymphatic system (Severo et al., 1979).

The disease is associated with many factors, some of them concerning the fungus, such as fungal strain and virulence, (San-Blas \& San-Blas, 1977) and others related to host competence (Robledo et al., 1982). Few attempts have been made to determine what cellular factor(s) might be

Abbreviations: $\mathrm{CW}-265$, cell wall from $P$. brasiliensis $\mathrm{Pb} 265$; $\mathrm{CW}$-HC, cell wall from $P$. brasiliensis $\mathrm{PbHC}$; 1 1-265, alkali-insoluble fraction isolated from CW-265; F1-HC, alkali-insoluble fraction isolated from CW-HC. responsible for the pathogenicity and virulence of this fungus. Thus, the objective of the present investigation was to explore the nature of the cell wall components of $P$. brasiliensis involved in inflammatory cell recruitment leading to the development of a mature granuloma which characterize the complex inflammatory process of paracoccidioidomycosis.

\section{METHODS}

Fungal strain and culture conditions. The virulent strain of $P$. brasiliensis $\mathrm{PbHC}$ was obtained from a paracoccidioidomycosis patient at the University Hospital, University of São Paulo, Ribeirão Preto, Brazil, and the avirulent strain Pb265 was kindly provided by Dr Marcelo Franco, UNESP, Botucatu, Brazil. Fungi were cultured at $37^{\circ} \mathrm{C}$ for $28 \mathrm{~d}$ in Fava Netto's medium (Fava Netto, 1961). The yeast cells were then harvested, autoclaved and washed seven times with distilled water.

Preparation of cell walls. The washed yeast cells were disrupted by ultrasonic vibration at $200 \mathrm{~W}$ for $3 \mathrm{~min}$; this process was repeated six times. A high degree of disruption was always observed by microscopy. The walls were collected and washed three times with distilled water by centrifugation at $5000 \mathrm{~g}$ for 
$10 \mathrm{~min}$. The wall samples were submitted to lipid extraction as previously described (Carareto Alves et al., 1987). The dried cell wall residues from $\mathrm{PbHC}$ and $\mathrm{Pb} 265$ were called $\mathrm{CW}-\mathrm{HC}$ and CW-265, respectively.

Partial fractionation of cell walls. CW-HC and CW-265 were suspended in $1 \mathrm{M} \mathrm{NaOH}\left(10 \mathrm{mg} \mathrm{m}^{-1}\right)$ and gently stirred at room temperature for $1 \mathrm{~h}$. After centrifugation at $5000 \mathrm{~g}$ for $10 \mathrm{~min}$, the supernatants were collected and the procedure repeated four times, combining all the supernatants and treated as described below. The alkali-insoluble sediment was washed with water until it reached $\mathrm{pH} 7 \cdot 0$ and then with ethanol, followed by acetone, and diethyl ether. The resulting white powder was incubated with trypsin $\left(100 \mu \mathrm{g} \mathrm{ml}^{-1}\right)$ in $0 \cdot(11 \mathrm{M}$ potassium phosphate buffer $(\mathrm{pH} 7 \cdot 2)$ for $4 \mathrm{~h}$ at $37^{\circ} \mathrm{C}$. After trypsin treatment, the suspensions were centrifuged at $20000 \mathrm{~g}$ for $10 \mathrm{~min}$, the supernatant solution was discarded, and the cell wall pellet was washed repeatedly with distilled water. The resulting sediment was called fraction F1-HC and F1-265, respectively.

The pooled supernatants obtained after treatment of cell walls with $\mathrm{NaOH}$, were neutralized with acetic acid and left to stand overnight at $4{ }^{\circ} \mathrm{C}$, after which a precipitate formed. The suspension was then centrifuged as before. The precipitate and the supernatant were collected, dialysed separately against distilled water and freeze-dried, yielding fractions F2 (alkalisoluble and precipitable with acid) and F3 (alkali-soluble and non-precipitable with acid), respectively.

Preparation of $\beta$-glucan by enzymic treatment of F1 fractions. Samples $(10 \mathrm{mg})$ of F1-HC or F1-265 fractions were incubated at $37^{\circ} \mathrm{C}$ for $24 \mathrm{~h}$ with $1 \mathrm{ml} 0.6 \mathrm{mg}$ chitinase $\mathrm{ml}^{-1}$ in $0.05 \mathrm{M}$ sodium acetate buffer $(\mathrm{pH} 5 \cdot 0)$ and $5 \mu \mathrm{l}$ toluene. After incubation, the supernatant was removed and the residue was further treated with chitinase. The procedure was repeated five times and the resulting sediment was washed with water and with ethyl alcohol and finally dried in an oven at $37^{\circ} \mathrm{C}$. The chitinase-treated $\mathrm{F} 1$ fractions were also submitted to the protease Pronase E (Sigma) treatment $\left(1 \mathrm{mg}\right.$ or 4 units $\left.\mathrm{ml}^{-\mathbf{1}}\right)$ for varying times at $37^{\circ} \mathrm{C}$ in a $0.05 \mathrm{M}$ Tris/ $\mathrm{HCl}$ buffer, $\mathrm{pH} 7.5$, containing $\left(\mathrm{ml}^{-1}\right): \mathrm{CaCl}_{2}, 555 \mu \mathrm{g}$; cycloheximide, $50 \mu \mathrm{g}$; and chloramphenicol, $25 \mu \mathrm{g}$. The resulting precipitates after several washes were called $\beta-\mathrm{HC}$ and $\beta-265$, obtained from F1-HC and F1-265, respectively.

Analytical procedures. Polysaccharide fractions were hydro lysed with $6 \mathrm{M} \mathrm{HCl}$ or with $1 \mathrm{M} \mathrm{HCl}$ at $110^{\circ} \mathrm{C}$ for $16 \mathrm{~h}$ in a sealed tube as previously described (San-Blas \& San-Blas, 1982). All glucose-containing samples were incubated with cellulase (EC 3.2.1.4), $\beta$-glucosidase (EC 3.2.1.21) or $\alpha$-glucosidase (EC 3.2.1.20), obtained from Sigma (1 mg or 10 units in $1 \mathrm{ml} 0.05 \mathrm{M}$ acetate buffer, $\mathrm{pH} 5.0$ ) and the mixture was incubated at $37^{\circ} \mathrm{C}$. After $24 \mathrm{~h}$ incubation, the reaction mixture was placed in a boiling-water bath for $5 \mathrm{~min}$ to inactivate the enzymes. Qualitative analysis for monosaccharides was performed by paper chromatography procedures described by Kanetsuna et al. (1969). Neutral sugars and amino sugars were visualized with alkaline silver nitrate reagent (Trevelyan $e t$ al., 1950) and Elson-Morgan reagent, respectively (Partridge, 1948). Glucose content was quantified by the phenol-sulphuric acid assay (Dubois et al., 1956), and glucosamine as described by Kanetsuma et al. (1969). Infrared spectra were recorded on $\mathrm{KBr}$ discs using a Shimadzu IR-27G spectrophotometer.

Animals. Male Wistar rats weighing $160 \cdot 0-180 \cdot 0 \mathrm{~g}$ and BALB/c mice weighing $18 \cdot 0-20 \cdot 0 \mathrm{~g}$ were used throughout.

Evaluation of leucocyte influx into the peritoneal cavity. Groups of six rats were injected intraperitoneally with a different amount of each preparation to be tested. At appropriate intervals thereafter the rats were killed with ether and injected intraperitoneally with $10 \mathrm{ml}$ of PBS-containing heparin. The abdomens were gently massaged and $5 \mathrm{ml}$ of blood-free cell suspension was carefully withdrawn with a syringe. Abdominal washings were placed in plastic tubes and total cell counts were performed immediately in a Neubauer Chamber. For differential counting a cell pellet was obtained by centrifugation and resuspended in $0.4 \mathrm{ml}$ PBS containing $3 \%(\mathrm{w} / \mathrm{v})$ bovine serum albumin. The cells were stained with May-Grunwald-Giemsa and differential counts (200 cells) were performed under the light microscope (Carareto Alves et al., 1987).

Examination of subcutaneous granulomas. Groups of four $\mathrm{BALB} / \mathrm{c}$ mice were injected subcutaneously into the ventral region with $100 \mu \mathrm{g}$ of fraction $\mathrm{F} 1-\mathrm{HC}$ or fraction F1-265 in $0.1 \mathrm{ml}$ PBS. Four mice in each group were sacrificed 4, 8, 16 and $32 \mathrm{~d}$, respectively, after injection and the lesions analysed macroscopically and subjected to histologic examination. For examination by light microscopy, the lesions were fixed in $10 \%$ formalin, embedded in paraffin, sectioned at $5 \mu \mathrm{m}$, and stained with hematoxylin and eosin $(\mathrm{H} \& \mathrm{E})$.

Statistical analysis. Student's $t$ test was used to compare the means of the experimental groups to the respective controls at a $5 \%$ significance level.

\section{RESULTS}

\section{Inflammatory cell recruitment into the peritoneal cavity of rats induced by $\boldsymbol{P}$. brasiliensis cell walls}

The total number of cells in the peritoneal fluid measured $24 \mathrm{~h}$ after injection of $1 \mathrm{mg}$ of CW-265 or CW-HC into the peritoneal cavity of rats is shown in Table 1 . Both cell wall preparations significantly increased the number of inflammatory cells in the peritoneal cavity when compared with the control group receiving only PBS $(P<0.001)$. Moreover, CW-265 induced a significantly greater migration than $\mathrm{CW}-\mathrm{HC}(P<0.002)$. Table 1 shows that when differential cell counts were performed on these peritoneal washouts, the number of polymorphonuclear and mononuclear cells was significantly increased in the CW-265 group when compared to the CW-HC group $(P<0.005)$ and to the control group $(P<0 \cdot 001)$.

Table 1. Inflammatory cells recruitment by cell wall fractions isolated from the fungus $P$. brasiliensis

Data representing a typical experiment are expressed as the mean \pm SEM for six rats in each group. Peritoneal cells were obtained $24 \mathrm{~h}$ after intraperitoneal inoculation of each fraction. Abbreviations: PMN, polymorphonuclear; MN, mononuclear.

\begin{tabular}{|lcrl|}
\hline $\begin{array}{l}\text { Fraction } \\
\text { injected }\end{array}$ & $\begin{array}{c}\text { Total cells } \\
\left(\mathbf{m m}^{-3}\right)\end{array}$ & $\begin{array}{c}\text { PMN cells } \\
\left(\mathbf{m m}^{-3}\right)\end{array}$ & $\begin{array}{c}\text { MN cells } \\
\left(\mathbf{m m}^{-3}\right)\end{array}$ \\
\hline Saline & $2640 \pm 790$ & $612 \pm 135$ & $2210 \pm 376$ \\
CW-265 & $8197 \pm 1179$ & $3120 \pm 560$ & $4440 \pm 723$ \\
CW-HC & $5320 \pm 712$ & $1790 \pm 356$ & $3140 \pm 234$ \\
F1-265 & $10850 \pm 980$ & $3780 \pm 610$ & $6050 \pm 590$ \\
F1-HC & $6640 \pm 470$ & $3490 \pm 356$ & $3716 \pm 345$ \\
\hline
\end{tabular}




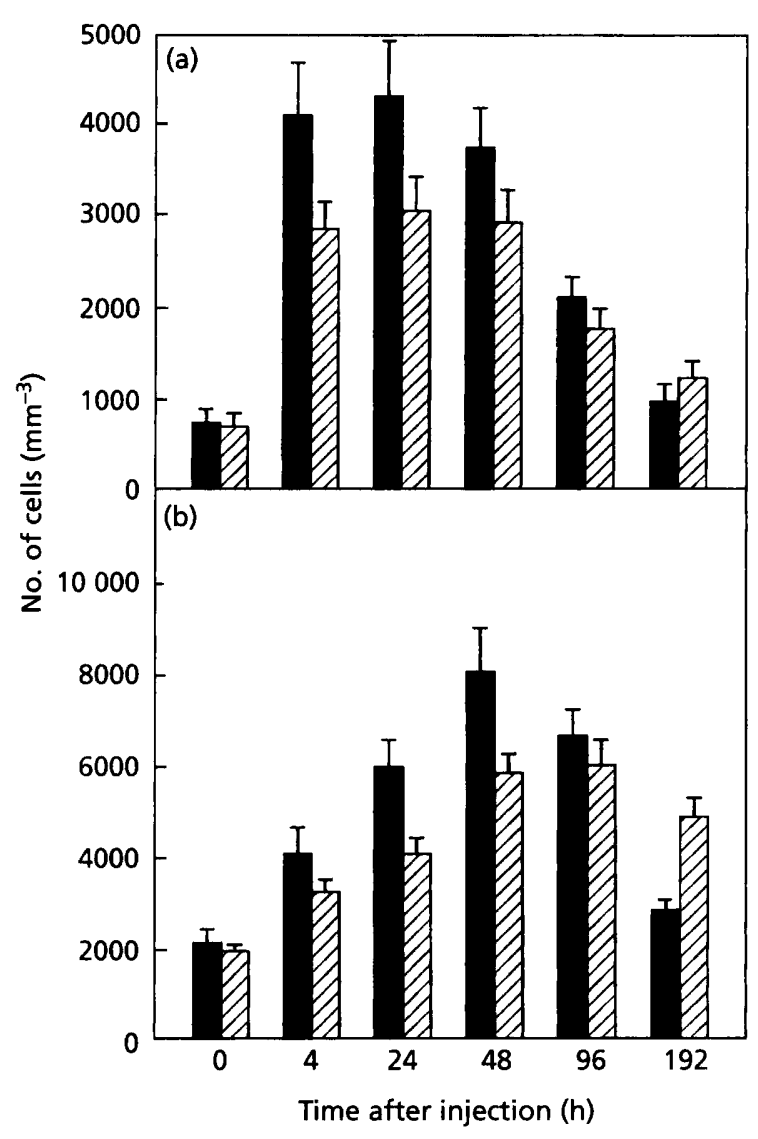

Fig. 1. Kinetics of the polymorphonuclear (a) and mononuclear (b) cell recruitment into the peritoneal cavity of rats induced by an injection of $100 \mu \mathrm{g} \mathrm{F1-265} \mathrm{( \square )} \mathrm{or} 100 \mu \mathrm{g} \mathrm{F1-HC} \mathrm{( \square ),}$ obtained from $\mathrm{CW}-265$ and $\mathrm{CW}-\mathrm{HC}$, respectively. Data representing a typical experiment are expressed as the mean \pm SEM for six rats in each group; experiments were repeated three times without significant differences.

\section{Comparison of the inflammatory cell recruitment activity induced in rats by F1-265 and F1-HC fractions}

In an attempt to determine which cell wall components are involved in the inflammatory cell recruitment activity, the CW-265 and CW-HC were fractionated according to their different solubilities in alkali. Thus, $46 \%$ and $21 \%$ were recovered as the alkali-insoluble F1-265 and F1-HC fractions from the same amount of CW-265 and CW-HC, respectively. When different amounts of both $F 1$ fractions were injected separately into the rat peritoneum, they produced a dose-dependent increase in total leucocytes $24 \mathrm{~h}$ after injection, although fivefold concentration of $\mathrm{F} 1-\mathrm{HC}$ was needed to induce the same biological effect as that of F1-265.

The kinetics of cell recruitment induced by both F1 fractions revealed a gradual increase in polymorphonuclear leucocytes which was highest 4 to $24 \mathrm{~h}$ after inoculation and which declined slowly over $48 \mathrm{~h}$ (Fig. 1a). In contrast, a secondary mononuclear cell phase beginning at $24 \mathrm{~h}$ and lasting up to $192 \mathrm{~h}$ after injection was observed for the F1-HC fraction (Fig. 1b). Interestingly, F1-265 was more active in inducing mononuclear cell recruitment between 24 and $96 \mathrm{~h}$ after injection than F1-HC. However, the cell recruitment activity of $\mathrm{F} 1-\mathrm{HC}$ was still present at $192 \mathrm{~h}$, a fact that was not observed for F1-265.

\section{Chemical, enzymic and spectroscopic analysis of F1 fractions}

Two hypotheses can be proposed: (a) the active components present in both F1 fractions may be different or (b) they may be the same but found in different concentrations. Quantitative analyses showed that both $\mathrm{F} 1$ fractions contained the same amount of glucosamine. However, glucose was twofold less abundant in the F1-HC than in F1-265. Chitinase treatment of both F1 fractions which were previously treated with trypsin and pronase, yielded a product characterized as $\beta$-glucan by infrared spectroscopy. Thus, the infrared spectra did not show absorption bands at 848 and $820 \mathrm{~cm}^{-1}$ due to $\alpha$-glycosidic linkages and did show a band at $895 \mathrm{~cm}^{-1}$ due to $\beta$ glycosidic linkages.

Moreover, cellulase and $\beta$-glucosidase treatment of F1$\mathrm{HC}$ and F1-265 yielded a product characterized as chitin by the same spectroscopic technique. The soluble component liberated after chitinase treatment was characterized as $N$-acetylglucosamine by paper chromatography, and the component liberated after treatment of the F1 fractions with $\beta$-glucosidase or cellulase was characterized as glucose. These results suggest that F1-HC and F1-265 contain chitin and $\beta$-glucan, with chitin found in the same amount in both fractions and $\beta$-glucans at a higher concentration in F1-265 than that in F1-HC.

\section{Comparison of the inflammatory cell migration activity induced by chitin and $\beta$-glucan}

To test whether chitin or $\beta$-glucan was responsible for the leucocyte cell migration activity of both $\mathrm{F} 1$ fractions, we isolated chitin (C-HC and $\mathrm{C}-265$, obtained from $\mathrm{F} 1-\mathrm{HC}$ and F1-265, respectively) and $\beta$-glucan ( $\beta \mathrm{G}-\mathrm{HC}$ and $\beta \mathrm{G}$ 265 , obtained from F1-HC and F1-265, respectively) by enzymic treatment as described above and looked for a leucocyte influx to the peritoneal cavity of rats 4, 24 and $48 \mathrm{~h}$ after intraperitoneal injection of the preparations. The results shown in Fig. 2 demonstrated that $\beta$-glucan is the active component of the F1 fractions of both strains of the fungus. A decrease in total leucocyte cell recruitment was observed at 24 and $48 \mathrm{~h}$ when compared to the influx observed at $4 \mathrm{~h}$ (Fig. 2), a phenomenon that was not observed when the F1 fractions from both strains were used as inflammatory stimuli. Moreover, injections of different amounts of $\beta \mathrm{G}-265$ and $\beta \mathrm{G}-\mathrm{HC}$ into rats produced a dose-dependent increase in total leucocytes $24 \mathrm{~h}$ after inoculation $(1952 \pm 198,3658 \pm 430,4946 \pm 787$, $8345 \pm 912$ and $9821 \pm 1076$ leucocytes counted in the peritoneal cavity of rats after injections of $0,10,50,100$ or $200 \mu \mathrm{g}$ of $\beta \mathrm{G}-265$, respectively; and $1817 \pm 159$, $3508 \pm 390,4700 \pm 819,7590 \pm 1070$ and $9704 \pm 990$ leucocytes counted after inoculation of the same amounts of $\beta \mathrm{G}-\mathrm{HC}$, respectively). 


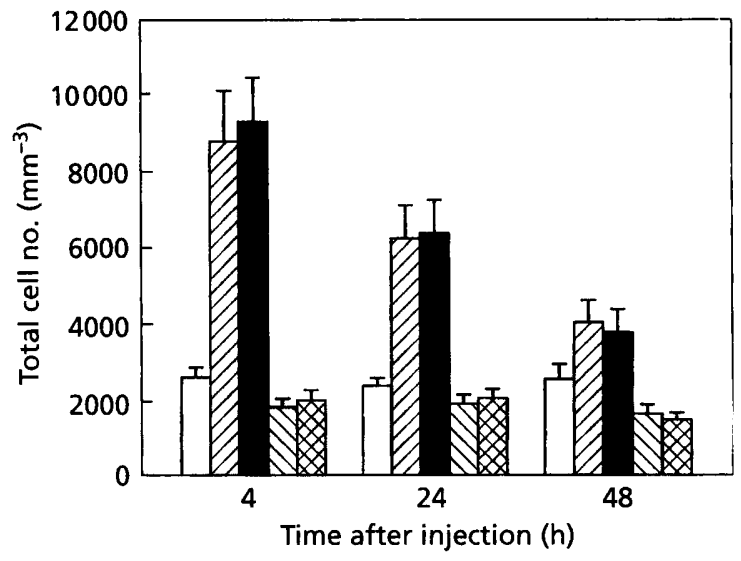

Fig. 2. Total leucocyte cell influx into the peritoneal cavity of rats induced by an injection 4,24 or $48 \mathrm{~h}$ before addition of $100 \mu \mathrm{g}$ of each of the following preparations: $\nabla, \beta \mathrm{G}-\mathrm{HC}(\beta-$ glucan recovered from $\mathrm{F} 1-\mathrm{HC}) ; \boldsymbol{Q}, \beta \mathrm{G}-265(\beta$-glucan recovered from F1-265); $\otimes, C-H C$ (chitin recovered from F1-HC); $\otimes, C-265$ (chitin recovered from F1-265). Data representing a typical experiment are expressed as the mean \pm SEM for six rats in each group. $\square$, PBS (negative control).

\section{Granuloma induced by the F1 fractions}

To test whether the F1 fractions recovered from the two strains differ in granuloma-inducing activity and whether inflammatory cell recruitment to the peritoneal cavity is correlated with subcutaneous inflammation, the F1-HC and F1-265 fractions were injected into the subcutaneous layer of mice $(100 \mu \mathrm{g}$ each) and the granuloma was evaluated $4,8,16$ and $32 \mathrm{~d}$ later. The inoculation of F1$\mathrm{HC}$ and F1-265 resulted in the formation of nodular, not progressive lesions. The size and mean time of evolution of these lesions was directly proportional to the degree of virulence of the sample from which they were derived. As shown in Fig. 3, the granuloma induced by F1-HC was observable until $32 \mathrm{~d}$, whereas the inflammatory reaction induced by F1-265 was more intense on the 4th and 8th days of observation and had resolved by $32 \mathrm{~d}$ after inoculation. Moreover, histological analysis showed that these granulomas were populated by an intense polymorphonuclear cell infiltrate during the early stages after inoculation, by polymorphonuclear and mononuclear cells during the middle stage, and by mononuclear cells during the final phase of the inflammatory process.

\section{DISCUSSION}

The data support the idea that leucocyte cell recruitment and granuloma formation in paracoccidioidomycosis depends on the polysaccharide composition of the agent which triggers attraction and concentric organization of polymorphonuclear neutrophils and macrophages at the inflammatory foci.

The importance of polymorphonuclear neutrophils in paracoccidioidomycosis has been suggested by the mass-
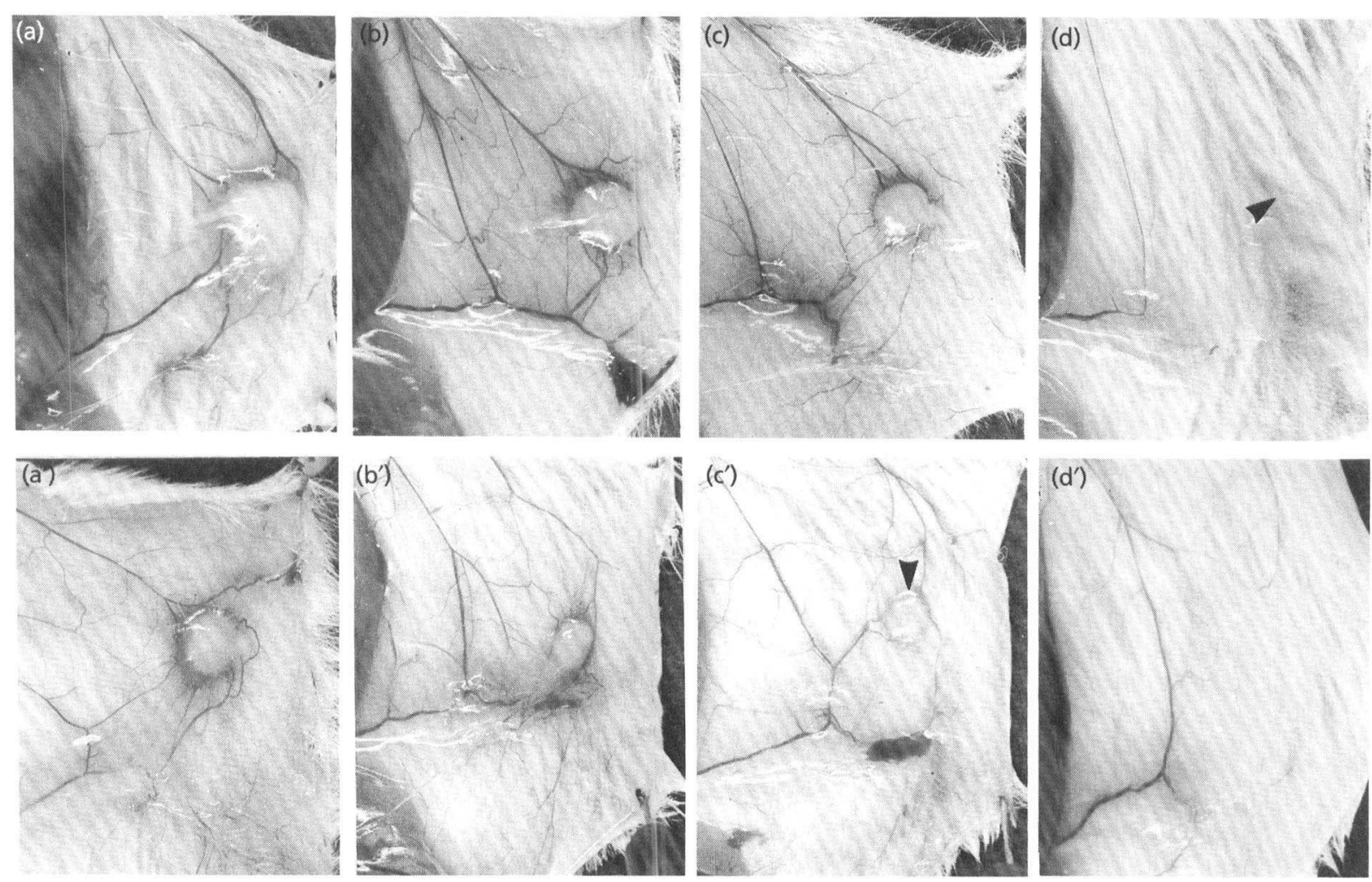

$\left(c^{\prime}\right)$
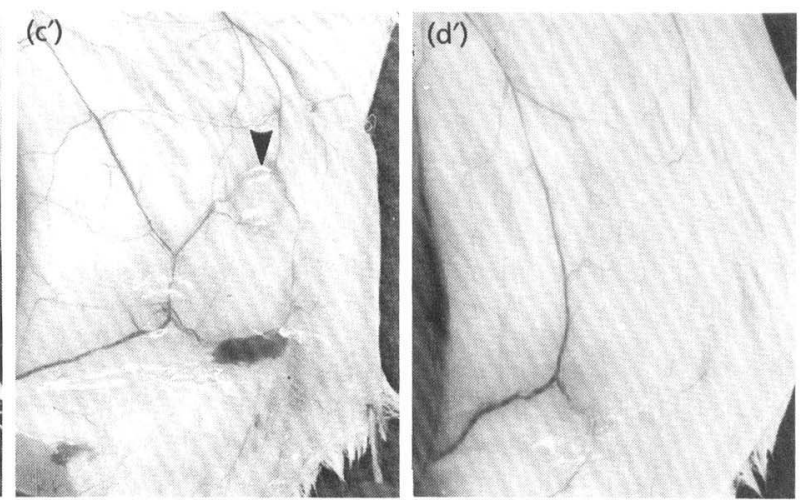

Fig. 3. Granuloma reaction observed in the site of inoculation of F1-HC (a-d) or F1-265 (a'-d'). Granuloma development at $4\left(a, a^{\prime}\right), 8\left(b, b^{\prime}\right), 16\left(c, c^{\prime}\right)$ and $32 d\left(d, d^{\prime}\right)$. Arrowheads indicate the mean time of evolution of these lesions. 
ive infiltration of these cells at the inflammatory sites during the initial stage of the disease in man (Franco \& Montenegro, 1982) as well as in experimentally infected animals (Carareto Alves et al., 1987; Silva \& Fazioli, 1985). The presence of polymorphonuclear neutrophils has also been detected in the suppurative region of the granulomatous lesions characteristic of the chronic phase of this mycosis (Bogliolo \& Lima Pereira, 1987; Figueiredo et al., 1986). Here, we demonstrated that a similar inflammatory response was observed when rats were injected with cell wall preparations or with polysaccharide cell wall fractions from $P$. brasiliensis, suggesting that these substances may play a role in the virulence and pathogenicity of this fungus.

Chemical and spectroscopic analysis showed that the chemical constituents present in both $\mathrm{F} 1$ fractions are similar, so that the element responsible for the induction of cell migration to the rat peritoneum may have been present in different concentrations in the two fungal strains studied. In fact, we found higher levels of $\beta$-glucan in F1-265 than in F1-HC. In contrast, chitin levels were identical in the two F1 fractions. Moreover, the results shown in Fig. 2 demonstrate that $\beta$-glucan was the main active component in both $\mathrm{F} 1$ fractions.

As demonstrated here, inflammatory reaction can be induced by $P$. brasiliensis cell wall components. Macrophages and cytokines such as tumour necrosis factor (TNF) may also play a pivotal role in these events. TNF levels have been associated with various infectious diseases (Scuderi et al., 1986), and high concentrations of circulating TNF have been demonstrated by our group in paracoccidioidomycosis (Silva \& Figueiredo, 1991). Moreover, the differences of TNF levels induced by both $F 1$ fractions when mice were injected intraperitoneally were correlated with the $\beta$-glucan concentrations in these fractions (Figueiredo et al., 1993). These findings support a role for the polysaccharide cell wall components of the fungus $P$. brasiliensis in inducing macrophage mediators such as TNF which might be a determining factor in the modulation of the inflammatory process in paracoccidioidomycosis.

There is a correlation between granuloma-inducing ability of $\mathrm{F} 1$ fractions as well as macrophage activation and chemotaxis with the metabolism of these fractions by the host cells, whose active component ( $\beta$-glucan) is continuously and slowly degraded. Cell wall components such as $\alpha$-glucan have been associated with the virulence of P. brasiliensis (San-Blas $e t$ al., 1977). This polysaccharide exists only in the parasitic yeast form of the fungus, but not in the mycelial form. The reduced cell wall $\alpha$-glucan in mutants or laboratory-passaged strains is directly correlated with a decrease in virulence. In contrast, mutants with a higher amount of $\alpha$-glucan have increased virulence. The avirulent strain Pb265, used here, contains 2.6fold less $\alpha$-glucan than the virulent $\mathrm{PbHC}$ strain as demonstrated in this study. We may conclude that the relatively greater proportion of $\beta$-glucan and the relatively lesser proportion of $\alpha$-glucan in the cell wall of $\mathrm{Pb} 265$ strain can explain its diminished virulence by the mech- anism of elicitation of a more vigorous inflammatory response and presumably more efficient clearance by the host. In contrast, the high proportion of $\alpha$-glucan, which is located more externally on the cell wall of the fungus (Kanetsuna et al., 1972), protects $\beta$-glucan from metabolism by the host (San-Blas \& San-Blas, 1982), whose active component is slowly degraded with a consequent continuous stimulus for a long period of time at the site of inoculation.

\section{ACKNOWLEDGEMENTS}

This research was supported by Fundação de Amparo à Pesquisa do Estado de São Paulo (FAPESP) and by Conselho Nacional de Pesquisa (CNPq). We thank S. L. Brandão Filho, I. Tincani Brandão and M. Heredia for their excellent technical support.

\section{REFERENCES}

Bogliolo, L. \& Lima Pereira, F. E. (1987). Inflamações. In Patologia, 4th edn, pp. 93-94. Edited by E. R. Lopes, E. Chapadeiro, P. Raso \& W. L. Tafuri. Rio de Janeiro: Guanabara Koogan.

Carareto Alves, L. M., Figueiredo, F., Brandão Filho, S. L., Tincani, I. \& Silva, C. L. (1987). The role of fractions from Paracoccidioides brasiliensis in the genesis of inflammatory response. Mycopatbologia 97, 3-7.

Dubois, M., Gilles, K. A., Hamilton, J., Rebers, P. A. \& Smith, F. (1956). Colorimetric method for determination of sugars and related substances. Anal Chem 28, 350-356.

Fava Netto, C. (1961). Contribuição para o estudo imunológico de Blastomicose de Lutz (Blastomicose Sul-Americana). Rev Inst Adolfo Lutz 21, 99-194.

Figueiredo, F., Silva, C. L., Alves, L. M. C. \& Rossi, M. A. (1986). Participation of Paracoccidioides brasiliensis lipids and polysaccharides in the evolution of granulomas. Braz J Med Biol Res 19, 651-653.

Figueiredo, F., Alves, L. M. C. \& Silva, C. L. (1993). Tumor Necrosis Factor production in vivo and in vitro in response to Paracoccidioides brasiliensis and the cell wall fractions thereof. Clin Exp Immunol 93, 189-194.

Franco, M. F. \& Montenegro, M. R. (1982). Anatomia patológica. In Paracoccidioidomicose, 1st edn, pp. 97-117. Edited by G. Del Negro, C. S. Lacaz, A. A. M. Fiorillo. São Paulo: sarvier-EDUSP.

Kanetsuna, F., Carbonell, L. M., Moreno, R. E. \& Rodriguez, J. (1969). Cell wall composition of the yeast and mycelial forms of Paracoccidioides brasiliensis. J Bacteriol 97, 1036-1041.

Kanetsuna, F., Carbonell, L. M., Azuma, I. \& Yamamura, Y. (1972). Studies on thermal dimorphism of Paracoccidioides brasiliensis. $J$ Bacteriol 110, 208-218.

Partridge, S. M. (1948). Filter-paper partition chromatography of sugars. I. General description and application to a qualitative analysis of sugars in apple juice, egg white and foetal blood of sheep. Biochem J 42, 238-250.

Restrepo, A., Greer, D. L. \& Vasconcelos, M. (1983). Paracoccidioidomycosis, a review. Rev Med Vet Mycol 8, 97-123.

Robledo, M. A., Graybill, J. R., Ahrens, J., Restrepo, A., Drutz, D. L. \& Robledo, M. (1982). Host defense against experimental paracoccidioidomycosis. Am Rev Respir Dis 125, 563-567.

San-Blas, G. \& San-Blas, F. (1977). Paracoccidioides brasiliensis. Cell wall structure and virulence. A review. Mycopatbologia 62, 77-86.

San-Blas, G. \& San-Blas, F. (1982). Variability of cell wall composition in Paracoccidioides brasiliensis: a study of two strains. Sabouraudia 20, 31-40. 
San-Blas, G., San-Blas, F. \& Serrano, L. E. (1977). Host-parasite relationships in the yeastlike form of Paracoccidioides brasiliensis strain IVIC Pb9. Infect Immun 15, 343-346.

Scuderi, P., Lam, K. S., Ryan, K. J., Petersen, E., Sterling, K. E., Finlay, P. R., Ray, C. G., Slymen, D. J. \& Salmon, S. E. (1986). Raised serum levels of tumour necrosis factor in parasitic infections. Lancet 2, 1364-1365.

Severo, L. C., Greyer, G. R., Londero, A. T., Porto, N. S. \& Rizzon, C. F. C. (1979). The primary pulmonary lymph node complex in paracoccidioidomycosis. Mycopatbologia 67, 115-118.
Silva, C. L. \& Fazioli, R. A. (1985). A Paracoccidioides brasiliensis polysaccharide having granuloma-inducing, toxic and macrophagestimulating activity. J Gen Microbiol 131, 1497-1501.

Silva, C. L. \& Figueiredo, F. (1991). Tumor Necrosis Factor in paracoccidioidomycosis patients. J Infect Dis 164, 1033-1034.

Trevelyan, W. E., Proctor, D. E. \& Harrison, J. S. (1950). Detection of sugars on paper chromatograms. Nature 166, 444-445.

Received 12 November 1993; accepted 29 November 1993. 